\title{
PENGARUH PENDEKATAN MELALUI KONSELING INTERPERSONAL TERHADAP RESPON SOSIAL, EMOSIONAL DAN SPIRITUAL PADA PASIEN HIV/AIDS
}

\author{
Indah Jayani $^{1)}$, Fatma Sayekti Ruffaida ${ }^{2}$ \\ ${ }^{1), 2)}$ Fakultas Ilmu Kesehatan Universitas Kadiri \\ E-mail: indah.jayani@,unik-kediri.ac.id
}

\begin{abstract}
Approach to PLWHA by providing interpersonal counseling is the right thing to do to overcome psychological problems including social, emotional and spiritual aspects of PLWHA. This study aims to look at the effect of interpersonal counseling on social, emotional and spiritual responses in HIVI AIDS patients. This research is a type of non-experimental research with a cross-sectional approach. The sample is post-test people and tested positive for HIV in the Kediri region, which is 32 with purpossive sampling technique. Data on social, emotional and spiritual responses were obtained based on the results of data recapitulation from the instrument in the form of a questionnaire. The results of the study with the nonparametric Wilcoxon test showed there were differences between social responses of HIVIAIDS patients before and after given interpersonal counseling with $p$ value $=0,000$, there were differences between the emotional responses of HIV/AIDS patients before being given interpersonal counseling and after being given counseling with $p$ value $=0,000$, and there is a difference between spiritual responses in HIV/AIDS patients before being given interpersonal counseling and after being given interpersonal counseling with $p$ value $=0,000$. It can be concluded that interpersonal counseling influences social, emotional and spiritual responses of HIV/AIDS patients. It is recommended that the mentoring of HIV/AIDS patients through interpersonal counseling can continue so as to enhance physiological responses that will have an impact on disease prognosis, prevention of opportunistic infections and reduce mortality rates for HIV patients/ AIDS.
\end{abstract}

Keywords: Interpersonal counseling; social response; emotional response; spiritual response, HIV / AIDS patients.

\begin{abstract}
ABSTRAK
Pendekatan pada ODHA dengan memberikan konseling interpersonal adalah hal yang tepat dilakukan untuk mengatasi permasalahan psikologis meliputi aspek sosial, emosional dan spiritual ODHA. Tujuan penelitian iniadalah melihat pengaruh konseling interpersonal terhadap respon sosial, emosional dan spiritual pada pasien HIV/AIDS. Penelitian ini merupakan jenis penelitian non experiment dengan pendekatan crossectional. Sampel dalam penelitian ini adalah orang pasca menjalani tes dan dinyatakan positif HIV di wilayah Kediri
\end{abstract}

Cara mengutip: Jayani, Indah \& Ruffaidah, F. Sayekti. (2020). Metode Pengaruh Pendekatan Melalui Konseling Interpersonal Terhadap Respon Sosial, Emosional, dan Spiritual pada Pasien HIV/AIDS. Care:Jurnal Ilmiah Ilmu Kesehatan, 8(1), 62-73 
yaitu sebanyak 32 dengan teknik purpossive sampling. Data respon sosial, emosional dan spiritual didapatkan berdasarkan hasil rekap data dari instrumen berupa kuesioner. Hasil penelitian dengan uji non parametrik Wilcoxon menunjukkan ada perbedaan antara respon sosial pasien HIV/AIDS sebelum dan sesudah diberikan konseling interpersonal dengan pvalue $=0,000$, ada perbedaan antara respon emosional pasien HIV/AIDS sebelum diberikan konseling interpersonal dan setelah diberikan konseling dengan $\mathrm{p}$-value $=0,000$, dan ada perbedaan antara respon spiritual pada pasien HIV/AIDS sebelum diberikan konseling interpersonal dan setelah diberikan konseling interpersonal dengan $\mathrm{p}$ value $=$ 0,000. Konseling interpersonal berpengaruh terhadap respon sosial, emosional dan spiritual pasien HIV/AIDS. Disarankan bahwa pendampingan pasien HIV/AIDS melalui konseling interpersonal dapat terus dilakukan sehingga dapat meningkatkan respon fisiologis yang berpengaruh terhadap prognosis penyakit, pencegahan infeksi oportunistik dan menurunkan angka mortalitas pasien HIV/AIDS.

Kata Kunci : Konseling interpersonal; respon sosial; respon emosional; respon spiritual, pasien HIV/AIDS

\section{PENDAHULUAN}

Permasalahan global yang dihadapi seluruh dunia termasuk Indonesia adalah penigkatan jumlah penderita akibat infeksi Humman Immunodeficiency Virus (HIV). Di Indonesia angka kejadian HIV/AIDS terus mengalami peningkatan setiap tahunnya untuk berbagai wilayah. Di Jawa Timur terjadi peningkatan kasus HIV yang signifikan,dimana dilaporkan sebanyak 43.399 penderita HIV/AIDS. Dari data tersebut diketahui bahwa Provinsi Jawa Timur merupakan urutan kedua setelah DKI Jakarta dengan kasus infeksi HIV tertinggi (Kementerian Kesehatan Republik Indonesia Direktorat Jendral Pencegahan dan Pengendalian Penyakit, 2017). Upaya pencegahan dan penanggulangan HIV/AIDS menjadi tanggungjawab bersama. Peran serta tenaga kesehatan dan masyarakat sangat diharapkan untuk mengatasi permasalahan HIV/AIDS yang kompleks. Meskipun terapi farmakoterapi terbukti dapat meningkatkan daya hidup penderita, tetapi ada hal lain yang perlu menjadi perhatian utama penatalaksanaan pada orang dengan HIV/AIDS (ODHA) yaitu masalah psikologi dan sosial. Permasalahan sosial yang dialami pasien HIV/AIDS diantaranya adalah menarik diri, gangguan sosialisasi, gangguan peran, kekhawatiran terhadap hubungan dengan pasangan, perubahan gaya hidup, kehilangan semangat akibat adanya pembatasan serta adanya perasaan terisolasi. Orang yang terdiagnosis HIV/AIDS cenderung mempunyai respon emosional, sosial dan spiritual yang negative. Ketika didiagnosis 
terinfeksi HIV seseorang akan berespon negatif. Respon tersebut dapat berupan perasaan berduka, marah, sedih bahkan depresi. Menurut(USAID, 2009)tahapan respon berduka seseorang bervariasi dimulai dari Denial, Anger, Bergaining, Depresi dan Acceptance. Pendekatan terhadap ODHA perlu dilakukan untuk meningkatkan motivasi ODHA agar dapat melanjutkan kehidupannya dengan meningkatkan semua aspek baik aspek fisik, emosional, sosial dan spiritualnya. Salah satu upaya pendekatan pada ODHA dilakukan dengan cara memberikan konseling interpersonal (USAID, 2009).

Konseling interpersonal merupakan komunikasi yang terjadi antara dua orang yang mempunyai hubungan yang terlihat jelas diantara mereka (Michael N.G Mizwa, 2009). Konseling interpersonal merupakan media motivasi yang baik untuk ODHA, sehingga timbul interaksi yang baik antara perawat atau konselor dalam proses penyembuhan penyakit dan pemberdayaan ODHA. Konseling Interpersonal merupakan titik tolak untuk saling memberikan pengertian antara perawat dengan klien. Konseling Interpersonal adalah proses pengiriman dan penerimaan pesan antara dua orang secara tatap muka dengan beberapa efek dan beberapa umpan balik secara seketika.
Konseling interpersonal merupakan konseling yang biasa dipakai untuk konseling pada ODHA karena membutuhkan privasi dan tidak ingin penyakitnya diketahui oleh orang. Dalam pelaksanaan konseling dengan menggunakan metode konseling individual ini memiliki kelebihan yaitu konselor lebih mudah terpusat kepada klien dan klien lebih mudah percaya kepada konselor (Diah Astuti Saputri Retnaningsih, 2016). Konseling interpersonal merupakan proses orang menciptakan dan mengelola hubungan, melaksanakan tanggung jawab secara timbal balik dalam menciptakan hubungan (All, 2007). Konseling interpersonal yang berpusat pada seseorang yang didiagnosis HIV positif merupakan salah satu intervensi kesehatan yang efektif sebagai upaya pencegahan penularan infeksi HIV lebih lanjut( MW Myrna . H. Sidney. MD. Hankerson. S. Pamela. O. Mark. V. Helena. S. Steve. MD. Shea. L. Rafael. W. Milton. MW, 2014). Konseling HIV/AIDS adalah konseling yang secara khusus memberi perhatian terhadap permasalahan yang berkaitan dengan HIV/AIDS, baik terhadap orang yang terinfeksi maupun terhadap lingkungan yang terpengaruh. Tujuan dari dilakukannya konseling HIV/AIDS agar tersedianya dukungan sosial dan 
psikologik pada ODHA dan keluarganya. Selain itu juga terjadinya perubahan perilaku yang aman sehingga penurunan penularan infeksi HIV/AIDS(Menteri Kesehatan Republik Indonesia, 2014) (Rakhmadi, 2010).

Pendekatan pada ODHA dengan memberikan konseling interpersonal adalah hal yang tepat dilakukan untuk mengatasi permasalahan psikologis meliputi aspek sosial, emosional dan spiritual ODHA. Konseling interpersonal adalah komunikasi yang terjadi antara dua orang yang mempunyai hubungan yang terlihat jelas diantara mereka dalam hal ini yang terlibat adalah konselor dan pasien. Konseling interpersonal adalah proses melalui mana orang menciptakan dan mengelola hubungan mereka, melaksanakan tanggung jawab secara timbal balik dalam menciptakan makna(All, 2007). Respon psikologis ODHA meliputi; khawatir, frustrasi, kesedihan, berduka, ketakutan anggota keluarga menjadi terinfeksi, perasaan marah serta depresi dan ketakutan menghadapi kematian (UNAIDS, 2007), (Suzanne C. O'Connell Smeltzer. Brenda G. Bare. Janice L.Hinkle, 2010). Individu memberikan respon setelah seseorang atau kelompok orang merasakan adanya suatu objek dan dilaksakan, kemudian dintepretasiobjek dan dilaksanakan, kemudian dinitepretasi objek yang dirasakan tersebut. Dapat diartikanbahwa respon sebenarnya adalah proses pemahaman terhadap apa yang terjadi dilingkungan dengan manusia dan tingkah lakunya, merupakan hubungan timbal balik, saling terkait dan saling mempengaruhi (B. Zani. E.D Pienaar. Oliver J. .Siegfied N, n.d.).

Feed back yang diharapkan dengan pendekatan melalui konseling interpersonal penerimaan ODHA akan lebih baik sehingga respon emosional, sosial dan spiritual meningkat ke arah positif. Dengan respon emosional, sosial dan spiritual yang positif maka diharapkan penerimaan ODHA terhadap dirinya lebih baik sehingga timbul motivasi yang kuat untuk mempertahankan hidup dengan meningkatkan kualitas hidupnya. Berbagai pendekatan digunakan oleh konselor dalam memberikan penyuluhan pendidikan dan pencegahan kepada orang-orang yang berisiko dan juga orangorang yang telah terinfeksi virus dan tidak ada satu metode yang lebih unggul dari yang lain dan beberapa teknik dipraktekkan oleh konselor HIV/AIDS (S.K Amar, 2011). Dari hasil wawancara 10 orang dengan HIV/AIDS di wilayah Kediri didapatkan 60\% menyebutkan 
bahwa cenderung membatasi berhubungan dengan orang lain, takut dan menarik diri, sering menangis dan menyalahkan Tuhan karena penyakitnya. Permasalahan diatas merupakan landasan peneliti untuk melakukan penelitian tentang efektivitas konseling interpersonal terhadap respon sosial, emosional, spiritual pada pasien HIV/AIDS.

\section{METODE PENELITIAN}

Desain penelitian ini menggunakan penelitian non experiment dengan pendekatan crossectional. Populasi adalah orang pasca menjalani tes dan dinyatakan positif HIV sebanyak 34 dan dengan teknik Purpossive sampling didapatkan sampel sebanyak 32. Kriteria inklusi pada penelitian ini adalah orang yang terdiagnosis HIV/AIDS berusia $\geq 12$ tahun yang kooperatif dan tidak menderita komplikasi infeksi oportunistik yang serius. Pengumpulan data dilakukan setelah responden menandatangani informed consent. Proses pemberian konseling dilakukan secara privacy didalam satu ruangan. Konseling dilakukan satu kali yaitu pasca test HIV/AIDS yang sudah dinyatakan positif. Konseling dilaksanakan selama 3060 menit. Data respon sosial, emosional dan spiritual didapatkan berdasarkan hasil rekap data dari instrumen berupa kuesioner. Analisa data dilakukan dengan uji non parametrik Wilcoxon..

\section{HASIL}

Hasil penelitian berdasarkan karakteristik responden untuk jenis kelamin,usia, status marital, pendidikan, pekerjaan, lama terinfeksi HIV dapat dilihat pada tabel 1.

Tabel 1. Karakteristik Responden Berdasarkan jenis kelamin, usia, status marital, pendidikan, pekerjaan dan lama terinfeksi HIV.

\begin{tabular}{|c|c|c|}
\hline Variabel & f & $(\%)$ \\
\hline \multicolumn{3}{|l|}{ Jenis Kelamin } \\
\hline Laki-laki & 12 & 37,5 \\
\hline Perempuan & 20 & 62,5 \\
\hline \multicolumn{3}{|l|}{ Usia } \\
\hline 12-18 tahun & 3 & 9,4 \\
\hline 19-30 tahun & 19 & 59,4 \\
\hline $31-55$ tahun & 10 & 31,2 \\
\hline$>55$ tahun & 0 & 0 \\
\hline \multicolumn{3}{|l|}{ Status Marital } \\
\hline Belum Menikah & 4 & 12,5 \\
\hline Menikah & 23 & 71,9 \\
\hline Duda/Janda & 5 & 15,6 \\
\hline \multicolumn{3}{|l|}{ Pendidikan } \\
\hline Dasar & 3 & 9,4 \\
\hline Menengah & 25 & 78,1 \\
\hline Tinggi & 4 & 12,5 \\
\hline \multicolumn{3}{|l|}{ Pekerjaan } \\
\hline Ibu Rumah Tangga & 1 & 3,1 \\
\hline Swasta & 10 & 31,3 \\
\hline PNS & 4 & 12,5 \\
\hline $\begin{array}{l}\text { Pekerja Seks Komersial } \\
\text { Aktif }\end{array}$ & 8 & 25,0 \\
\hline Eks $\quad$ Pekerja & 9 & 28,1 \\
\hline \multicolumn{3}{|l|}{ Komersial } \\
\hline Lainnya & 0 & 0 \\
\hline \multicolumn{3}{|l|}{ Lama terinfeksi HIV } \\
\hline$<6$ bulan & 8 & 25,0 \\
\hline 6-12 bulan & 17 & 53,1 \\
\hline$>12$ bulan & 7 & 21,9 \\
\hline
\end{tabular}

Sumber : Data penelitian, 2019 
Berdasarkan Tabel 1. menunjukkan bahwa karakteristik responden berdasarkan jenis kelamin sebagian besar (62,5\%) adalah perempuan dan sebagian besar $(59,4 \%)$ adalah berusia reproduktif (19-30 tahun).Karakteristik status marital responden sebagian besar $(71,9 \%)$ menikah, pendidikan responden hampir seluruhnya $\quad(78,1 \%) \quad$ berpendidikan menengah. Sedangkan untuk karakteristik ekerjaan responden sebagian besar $(53,1 \%)$ adalah pekerja seksual baik yang masih aktif maupun eks pekerja seksual komersial.

Tabel 2. Distribusi frekuensi respon sosial, emosional dan spiritual pra konseling.

\begin{tabular}{|c|c|c|c|c|c|c|c|}
\hline \multirow{3}{*}{ Respon } & \multicolumn{6}{|c|}{ Pra Konseling } & \multirow{2}{*}{ Total } \\
\hline & Kurang & & $\mathrm{Cul}$ & & $\mathbf{B a}$ & & \\
\hline & $\sum$ & $\%$ & $\sum$ & $\%$ & $\sum$ & $\%$ & $\sum$ \\
\hline Sosial & 24 & 75 & 8 & 25 & 0 & 0 & 32 \\
\hline Emosional & 21 & 65,6 & 11 & 34,4 & 0 & 0 & 32 \\
\hline Spiritual & 17 & 53,2 & 10 & 31,2 & 5 & 15,6 & 32 \\
\hline
\end{tabular}

Berdasarkan tabel 2. Dapat dilihat bahwa sebelum diberikan konseling interpersonal respon sosial sebagian besar $(75 \%)$ respon sosial responden dalam katagori kurang, respon emosional sebagian besar $(65,6 \%)$ juga dalam kategori kurang, demikian juga respon spiritual sebagian besar $(53,2 \%)$ dalam kategori kurang.

Tabel 3. Distribusi frekuensi respon sosial, emosional dan spiritual post konseling.

\begin{tabular}{|c|c|c|c|c|c|c|c|}
\hline \multirow[t]{3}{*}{ Respon } & \multicolumn{6}{|c|}{ Pra Konseling } & \multirow[t]{2}{*}{ Total } \\
\hline & Kurang & & $\mathrm{Cu}$ & & Baik & & \\
\hline & $\sum$ & $\%$ & $\sum$ & $\%$ & $\sum$ & $\%$ & $\sum$ \\
\hline Sosial & 1 & 3,1 & 26 & 81,3 & 5 & 15,6 & 32 \\
\hline Emosional & 0 & 0 & 23 & 71,9 & 9 & 28,1 & 32 \\
\hline Spiritual & 0 & 0 & 22 & 68,8 & 10 & 31,2 & 32 \\
\hline
\end{tabular}

Berdasarkan Tabel 3. Dapat dilihat bahwa setelah diberikan konseling interpersonal respon sosial hampir seluruhnya $(81,3 \%)$ respon sosial responden dalam katagori cukup, respon emosional sebagian besar $(71,9 \%)$ juga dalam kategori cukup, demikian juga respon spiritual sebagian besar $(68,8 \%)$ dalam kategori cukup.

\section{PEMBAHASAN}

Respon sosial seseorang terhadap HIV/AIDS sangat bervariasi, tergantung beberapa faktor diantaranya adalah 
pengetahuan, pendidikan, status marital serta lama terinfeksi HIV. Pada penelitian ini didapatkan bahwa pendidikan responden hampir seluruhnya $(78,1 \%)$ adalah menengah, sehingga memungkinkan pengetahuan responden mengenai penyakit dan penataksanaan kurang karena proses penyerapan informasi yang kurang. Selain itu faktor keluarga dapat menjadi salah satu pengaruh terkuat dalam kehidupan ODHA. Status marital menggambarkan bahwa responden yang belum menikah dan dengan status duda/janda tidak mempunyai pasangan sebagai keluarga terdekat, termasuk dalam pengambilan keputusan.

Lama terinfeksi HIV juga berpengaruh terhadap respon sosial pasien HIV/AIDS. waktu yang relatif lama mempengaruhi respon orang yang terdiagnosis HIV/AIDS. Tahapan respon penerimaan pasien bervariasi dimulai dari Denial, Anger, Bergaining, Depresi dan Acceptance. Pasien yang terdiagnosis $<6$ bulan cenderung memiliki perilaku diam dan menarik diri. Lamanya proses penerimaan keadaan dirinya berhubungan dengan mekanisme koping masing-masing individu.
Hasil menunjukkan bahwa responden pada respon emosional sebelum diberikan konseling interpersonal sebagian besar $(65,6 \%)$ dalam kategori kurang, sedangkan respon emosional setelah diberikan konseling interpersonal sebagian besar (71,9\%) dalam kategori cukup. Pada variabel respon emosional didapatkan $\mathrm{p}$ value $=0,00$ sehingga dapat disimpulkan ada perbedaan respon emosional responden sebelum dan setelah diberikan konseling interpersonal. Emosional didefinisikan sebagai keadaan perasaan yang kompleks yang menghasilkan perubahan fisik dan psikologis yang memengaruhi pemikiran dan perilaku. Emosionalitas dikaitkan dengan serangkaian fenomena psikologis, termasuk temperamen, kepribadian, suasana hati, dan motivasi. Teori fisiologis menunjukkan bahwa respons dalam tubuh bertanggung jawab atas emosi. Teori neurologis mengusulkan bahwa aktivitas di dalam otak mengarah pada respons emosional. Teori kognitif berpendapat bahwa pikiran dan aktivitas mental lainnya memainkan peran penting dalam membentuk emosi (Cherry, 2019). Individu yang didiagnosis HIV/ AIDS akan mengalami tekanan emosional serta stress psikologis takut dikucilkan keluarga dan masyarakat, terutama keluarga takut tertular, serta adanya stigma sosial dan 
diskriminasi di masyarakat (Setyowati., 2009). Pasien HIV/ AIDS harus bisa menerima keadaan dengan ikhlas dan harus mempunyai semangathidup sehingga tetap bisa produktif. Kondisi tersebut dapat t pada ODHA yang secara kejiwaan lemah, tak bisa menerima kenyataan hidup (S, 2016). Stres psikososial-spiritual pasien terinfeksi HIV berlanjut akan memperberat komplikasi AIDS dan munculnya berbagai infeksi oportunistik dan mempercepat kematian. Keadaan stres dapat menimbulkan kegagalan fungsi sistem imun, yang memperparah keadaan pasienyang mencapai tingkat exhausted stage(W. F. Maramis, 2003). Sesuai dengan konsep ilmu psikoneuroimunologi, melalui sel astrosit pada cortical dan amigdala pada sistem limbik berefek pada hipotalamus. Kemudian hipofisis akan menghasilkan CRF, yaitu pada sel basofi. Sel basofi tersebut akan mengekspresikan ACTH (adrenal cortico tropic hormone) yang dapat memengaruhi kelenjar kortek adrenal pada sel zona fasiculata, kelenjar ini akan menghasilkan kortisol yang bersifat immunosupressive. Kelenjar adrenal akan menghasilkan kortisol dalam jumlah banyak sehingga dapat menekan sistem imun, yang meliputi aktivitas APC (makrofag); Th-1 (CD4); dan sel plasma: IFN $\gamma ;$ IL-2; IgM - IgG dan Antibodi-
HIV [20]. Upaya peningkatanrespon emosional dengan memberikan konseling terbukti efektif karena proses yang dilalui menekankan pada pentingnya menjalin hubungan, penerimaan klien, eksplorasi, identifikasi, memberi informasi, perencanaan kegiatan, menentukan keputusan, sampai pada membangun kesiapan klien, membuat perencanaan, memberikan penjelasan dan memberikan dukungan, semangat, dan motivasi sehingga kepercayaan diri pasien meningkat dan optimistis dalam menjalani kehidupan.

Hasil penelitian pada respon spiritual didapatkan sebagian besar $(53,1 \%)$ dalam kategori kurang dan setelah diberikan konseling interpersonal sebagian besar (71,9\%) dalam kategori cukup. Salah satu bentuk mekanisme pertahanan diri manusia/ koping adalah strategi koping religius yaitu melibatkan agama dalam penyelesaian masalah dengan meningkatkan ritual keagamaan sehingga akan mengurangi tekanan ataupun stresor yang dialami. Analisa data dilakukan untuk melihat perrbedaan respon spiritual sebelum dan setelah diberikan konseling interpersonal didapatkan $\mathrm{p}$ value $=0,00$ sehingga dapat disimpulkan ada perbedaan respon spiritual responden 
Care: Jurnal Ilmiah Ilmu Kesehatan Vol .8, No.1, 2020, hal 62-73

sebelum dan stelah diberikan konseling interpersonal.

Menurut asumsi peneliti responden yang telah mendapatkan konseling interpersonal berupa informasi pengetahuan yang mendalam tentang pemahaman penyakit, prognosis serta penguatan spiritual sehingga spiritualitas responden meningkat. Rerponden mulai memahami tentang penyakitnya, bagaimana prognosisnya, upaya apa saja yang dapat dilakukan untuk mencegah komplikasi seperti infeksi oportunistik dan kematian. Dalam perawatan pasien paliatif harus menggabungkan aspek fisik, sosial, emosional dan spiritual. Wacana spiritual yang luas dapat mencakup hubungan, makna dan tujuan, kasih sayang, harapan, dan pengampunan(Julie Fletcher, 2016). Hasil penelitian ini sejalan dengan penelitian sebelumnya yang menyebutkan $45 \%$ responden mengalami spiritualitas positif yang meningkat setelah diagnosis HIV. Peningkatan respon spiritual positif pasien dengan HIV dapat meningkatkan respon fisiologis pada pasien HIV, dibandingkan dengan pasien yang spiritualitasnya menurun setelah diagnosis HIV(Trevino, K.M., Pargament, K.I., Cotton, S., 2010). Penelitian lain juga menyebutkan hal yang sama bahwa seseorang dengan diagnosis medis penyakit terminal seperti kanker, gagal jantung kongestif, penyakit paru obstruktif memiliki spiritualitas lebih (OR $=1,61 ; 95 \% \mathrm{CI}=1,03,2,52)$. Aspek spiritualitas menjadi hal yang sangat penting diperhatikan karena dengan meningkatnya kerohanian seseorang maka akan cenderung lebih mampu beradaptasi dan menerima kondisinya. Kecenderungan respon spiritual negatif seperti perjuangan spiritual, kemarahan pada Tuhan, atau memandang HIV sebagai dosa dikaitkan dengan kepatuhan medis yang buruk, dan pengembangan penyakit yang lebih cepat (Trevino, K.M., Pargament, K.I., Cotton, S., 2010). Oleh karena itu, jenis keyakinan dan praktik spiritual akan membantu menentukan apakah spiritualitas akan menjadi faktor pelindung atau berisiko terhadap perkembangan penyakit HIV.

Hasil ini tidak sesuai dengan data menurut (Kementerian Kesehatan Republik Indonesia Direktorat Jendral Pencegahan dan Pengendalian Penyakit, 2017)yang menyebutkan bahwa rasio penderita infeksi HIV berdasarkan jenis kelamin adalah laki-laki yaitu 2:1. Penelitian lain menyebutkan etnis laki-laki dengan ras kulit hitam beresiko terhadap perilaku beresiko HIV AIDS (Jeffrey A. et.al, 2013). 
Data penelitian menunjukkan perbedaan dimana didapatkan bahwa perempuan lebih banyak dibandingkan dengan lakilaki dikarenakan sebagian besar esponden $(53,1 \%)$ mempunyai pekerjaan pekerja seksual komersial (PSK) baik aktif maupun eks PSK sehingga jenis kelamin didominasi oleh perempuan. Usia responden terbanyak pada rentang usia 19-30 tahun (59,3\%), dimana hal ini sesuai dengan data dari (Kementerian Kesehatan Republik Indonesia Direktorat Jendral Pencegahan dan Pengendalian Penyakit, 2017)yang menyebutkan bahwa presentase tertinggi adalah pada kelompok umur 25-49 tahun yaitu sebanyak 69,2\%. Usia produktif memungkinkan seseorang melakukan hubungan seksual aktif sehingga berisiko untuk penularan infeksi HIV yang tinggi. Untuk karakteristik responden berdasarkan status marital sebagian besar $(71,9 \%)$ adalah menikah. Meskipun sebagian besar responden adalah pekerja seksual yang aktif maupun eks PSK tetapi masih memiliki keluarga ditunjukkan bahwa status marital dari responden sebagian besar adalah menikah. Pada karakteristik pendidikan hampir seluruhnya $(78,1 \%)$ mempunyai riwayat pendidikan menengah. Pendidikan dapat mempengaruhi seseorang termasuk perilaku seseorang akan pola hidup terutama dalam memotivasi untuk sikap yang berperan serta dalam pembangunan, makin tinggi tingkat pendidikan seseorang makin mudah menerima informasi (Wawan, A dan Dewi, 2010). Pengetahuan dan pemahaman Orang Dengan HIV/AIDS (ODHA) yang sangat kurang berpengaruh terhadap kondisi kesehatan mereka(R. Nancy, 2016). Adopsi perilakuatau penerimaan perilaku baru melalui proses yang didasari adanya pengetahuan, sikap yang positif dan kesadaran, sehingga perilaku tersebut akan bersifat langgeng (long lasting) dibandingkan perilaku yang tanpa didasari oleh pengetahuan (Notoatmodjo, 2012). Berdasarkan lama terinfeksi HIV sebagian besar (53,1\%) adalah 6-12 bulan. Penerimaan seseorang terhadap respon berduka melalui beberpa tahapan dan dipengaruhi oleh waktu.

Banyak dari pasien HIV/AIDS yang telah terinfeksi berperilaku tertutup dalam artian tidak mau menceritakan kepada orang lain baik teman, keluarga atau koordinator pasien HIV/AIDS bahwa telah terinfeksi. Manusia sebagai makhluk sosial, tidak mampu memenuhi kebutuhan hidupnya tanpa ada hubungan dengan lingkungan sosialnya. Hubungan dengan orang lain dan lingkungan sosialnya menimbulkan respon sosial pada 
seseorang.. Disebutkan bahwa rentang respon sosial seseorang berada dalam rentang adaptif sampai dengan maladaptif (Stuart Gail W, 2007).

\section{KESIMPULAN}

Sebelum diberikan konseling interpersonal menunjukkan respon sosial kurang (75\%), respon emosional kurang $(55,6 \%)$ dan respon spiritual yang juga kurang (53,2\%). Setelah diberikan konseling interpersonal responden menunjukkan respon sosial cukup $(81,3 \%)$, respon emosional cukup $(71,9 \%)$, respon spiritual cukup $(68,8 \%)$. Ada perbedaan yang signifikan antar sebelum dan setelah diberikan konseling interpersonal dengan $\mathrm{p}$ value $=0,00$

\section{SARAN}

Disarankan bahwa pendampingan pasien HIV/AIDS melalui konseling interpersonal dapat terus dilakukan sampai pasien bisa menerima keadaan dirinya ditunjukkan dengan respon sosial, emosional dan spiritual yang positif sehingga meningkatkan respon fisiologis positif yang akan berdampak pada perkembangan penyakit HIV/AIDS.

\section{UCAPAN TERIMAKASIH}

Terimakasih diucapkan oleh tim peneliti kepada Ristek Dikti yang telah mendanai penelitian ini dan Universitas Kadiri yang memberikan dukungan dalam menyelesaikan penelitian ini.

\section{REFERENSI}

All, V. K. et. (2007). Interpersonal Communication Concept, Skill and Context. International Act.

B. Zani. E.D Pienaar. Oliver J. .Siegfied N. (n.d.). "Randomized controlled trials of HIV / AIDS prevention and treatment in Africa: results from the Cochrane HIV / AIDS Specialized Register."

Cherry, K. (2019). Father of American Psychology: Psychology Theory. William James Biography.

Diah Astuti Saputri Retnaningsih. (2016). Voluntary Counseling and Testing untuk Orang Berisiko HIV/AIDS. J. Dakwah Dan Komun.

Julie Fletcher. (2016). Spiritual Screening in Community-Based Palliative Care by the Multidisciplinary Team. J. Relig. Health, 58.

Kementerian Kesehatan Republik Indonesia Direktorat Jendral Pencegahan dan Pengendalian Penyakit. (2017). Laporan Perkembangan HIV-AIDS \& Infeksi Menular Seksual (IMS) Triwulan IV Tabun 2017 (Kementrian Kesehatan Republik Indonesia, ed.).

Menteri Kesehatan Republik Indonesia. (2014). PERATURAN MENTERI KESEHATAN NOMOR 74, PEDOMAN PELAKSANAAN KONSELING DAN TES HIV.

Michael N.G Mizwa. (2009). Hiv Prevention Counseling.

MW MYRNA . H. SIDNEY. MD. HANKERSON. S. PAMELA. O. MARK. V. HELENA. S. STEVE. MD. SHEA. L. RAFAEL. W. MILTON. MW. (2014). Interpersonal Counseling (IPC) for Depression in Primary Care. HHS Public Access, 68(4), 359-383. 
Notoatmodjo, S. (2012). Promosi Kesehatan dan Perilaku Kesehatan. Jakarta : Rineka Cipta.

R. Nancy. (2016). DUKUNGAN KELUARGA TERHADAP KELANGSUNGAN HIDUP ODHA (ORANG DENGAN HIV/AIDS). INSANI, 3(2).

Rakhmadi, K. (2010). Supervisor Pendidikan Pelatihan dan Penelitian. UPT HIV RCM Hallo Cipto.

S.K Amar. (2011). HIV/AIDS Counseling Skills and Strategies: Can Testing and Counseling Curb the Epidemic. Int. J. Prev. Med, 2(1), 10 14.

S, Y. (2016). Influence of Depression to Quality of Life People Living with HIV/AIDS after Antiretroviral Treatment. 02, 96101.

Setyowati., G. W. C. \& H. (2009). Lembaran Informasi tentang HIVI AIDS untuk Orang dengan HIVI AIDS (ODHA).

Stuart Gail W. (2007). Buku Saku Keperawatan Kesehatan Jiwa. Jakarta: EGC.
Suzanne C. O'Connell Smeltzer. Brenda G. Bare. Janice L.Hinkle, B. \& S. (2010). Text Book of Canadian Medical Surgical.

Trevino, K.M., Pargament, K.I., Cotton, S., L. (2010). Religious coping and physiological, psychological, social, and spiritual outcomes in patients with HIV/AIDS: Cross-sectional and longitudinal findings.," AIDS Behav. AIDS Behav, 14.

UNAIDS. (2007). Guidance on provider initiated HIV testing and counceling in bealth fasilities.

USAID. (2009). Psychososial care and counseling for HIV invected children and adolescent. Baltimore: Chatolic Relief Service, (Revised).

W. F. Maramis. (2003). Catatan Ilmu Kedokteran Jiwa. Surabaya: Airlangga University Press., 2003. Surabaya: Airlangga University Press.

Wawan, A dan Dewi, M. (2010). Teori dan Pengukuran Pengetabuan, Sikap dan Perilaku Manusia.. Yogyakarta: Nuha Medika. 